\title{
KONFLIK TENTANG GANTI RUGI NON FISIK PADA PENGADAAN TANAH UNTUK KEPENTINGAN UMUM
}

\author{
Iga Gangga Santi Dewi \\ Fakultas Hukum Universitas Diponegoro \\ Jl. Prof. Soedarto, SH Tembalang, Semarang \\ ganggasanti@yahoo.com
}

\begin{abstract}
Many conflict between government and citizens related to the process of land acquisition for development for the public interest. The problem was suspected because the resident did not accept the government's decision on the form and amount of non physical compensation. The research method used the paradigm of constructivism with case study. Research needs to rebuild a non physical compensation policy on land acquisition for public purposes with a social justice based value. Non physical compensation conflicts on land acquisition for the public interests are seen as a phenomenon that the compensation policy Law No. 2 of 2012 on Land Procurement for Development for Public Interest, not executed properly so that violates Constitution of Indonesia.
\end{abstract}

Keywords: Conflict, Non Physical Compensation, Land Acquisition

\begin{abstract}
Abstrak
Banyak konflik antara pemerintah dan warga terkait proses pengadaan tanah bagi pembangunan untuk kepentingan umum. Permasalahan ditenggarai karena warga tidak menerima atas keputusan pemerintah mengenai bentuk dan besarnya ganti rugi non fisik. Metode penelitian menggunakan paradigma kontruktivisme dengan studi kasus konflik penentuan bentuk dan besarnya ganti rugi non fisik pengadaan tanah. Penelitian perlu untuk membangun kembali kebijakan ganti rugi non fisik pada pengadaan tanah untuk kepentingan umum dengan berbasis nilai keadilan sosial. Konflik ganti rugi non fisik pada pengadaan tanah untuk kepentingan umum dipandang fenomena bahwa kebijakan ganti rugi dalam Undang-Undang No. 2 Tahun 2012 tentang Pengadaan Tanah Bagi Pembangunan Untuk Kepentingan Umum, tidak dijalankan secara benar sehingga melanggar konstitusi UUD NRI Tahun 1945.
\end{abstract}

Kata Kunci : Konflik; Ganti Rugi Non Fisik; Pengadaan Tanah

\section{A. Pendahuluan}

1. Latar belakang Permasalahan

Tanah dalam kehidupan manusia mempunyai arti yang sangat penting, sebab sebagian besar dari kehidupan manusia bergantung pada tanah. Tanah adalah tempat bermukim bagi manusia dan sebagai sumber penghidupan mereka untuk mencari nafkah serta pada akhirnya manusia apabila meninggal akan kembali ke tanah. Di samping itu, tanah dapat pula dinilai sebagai suatu harta yang mempunyai sifat permanen karena memberikan kemanfaatan untuk direncanakan bagi berbagai kepentingan di masa-masa mendatang.
Kebutuhan tanah bagi pembangunan untuk kepentingan umum dilakukan dengan pengadaan tanah yang sebagian besar tanah hak warga dan masyarakat, disebabkan tanah negara tidak mencukupi lagi bagi pembangunan tersebut. Konsekuensinya, pengadaan tanah bagi pembangunan untuk kepentingan umum telah merambah hingga meliputi tanah-tanah milik penduduk yang meliputi tempat tinggal, tempat usaha baik pertanian, perkebunan serta perikanan milik pribadi warga maupun milik masyarakat (tanah kas desa) untuk kegiatan masyarakat juga tanah untuk peribadatan (masjid dan atau mushola). 
Masyarakat merasa terganggu kehidupannya, karena sumber perolehan uang untuk kebutuhan hidup sehari-hari juga kenyamanan hidup pribadi, keluarga dengan lingkungan sosialnya akan hilang dengan adanya pengadaan tanah apabila ganti rugi yang mereka terima tidak dapat mencukupi kebutuhan dan kepentingan mereka untuk saat ini dan masa yang akan datang yang telah mereka rencanakan sebelum adanya pengadaan tanah di daerah mereka. Misalnya, tanah yang selama ini menghasilkan panen sebagai perolehan uang untuk kepentingan masa depan anak yang masih sekolah akan hilang dan akan sangat merugikan apabila tidak diganti rugi non fisik oleh pemerintah. Pemerintah selama ini hanya memberikan ganti rugi fisik saja tanpa memperhatikan ganti rugi non fisik secara benar bagi warga tanahnya terkena pembangunan untuk kepentingan umum. Secara empirik, fenomena semacam itu menandai adanya perubahan dalam kehidupan pemilik tanah untuk ke depannya apabila ganti rugi non fisik tidak diberikan pada warga yang berhak atas obyek pengadaan tanah.

Berdasarkan data dari Konsorsium Pembaruan Agraria selama tahun 2014, jumlah konflik di sektor infrastruktur terkait ganti rugi dengan jumlah 215 konflik atau $45,55 \%$ yakni antara warga dengan pemerintah, yakni 115 kasus dan konflik antara warga dan perusahaan negara, yakni sebanyak 46 kasus. Berkaitan dengan banyaknya konflik antara pemerintah dan warga yang berhak mengenai bentuk dan besarnya ganti rugi non fisik, sehingga dipandang perlu untuk membangun kembali kebijakan ganti rugi non fisik pada pengadaan tanah untuk kepentingan umum dengan berbasis nilai keadilan sosial.Konflik-konflik tersebut, dapat dipandang sebagai fenomena bahwa kebijakan ganti rugi non fisik pada pengadaan tanah untuk kepentingan umum, yaitu di dalam Pasal 33 huruf (f) UndangUndang No. 2 Tahun 2012 tentang Pengadaan Tanah Bagi Pembangunan Untuk Kepentingan Umum (selanjutnya ditulis UUPT Tahun 2012) tidak dijalankan secara benar sehingga melanggar konstitusi UUD NRI Tahun 1945 dan Pancasila sebagai pedoman hidup bangsa Indonesia.
Fenomena ketidakadilan substantif pada kebijakan ganti rugi non fisik dalam pengadaan tanah ini menimbulkan kesenjangan ekonomi antara warga dan ketimpangan sosial dalam kehidupan masyarakat. Hal ini terjadi karena tidak diberikannya ganti rugi yang layak atas kehilangan hak-hak kenyamanan kehidupan mereka akibat adanya pembangunan untuk kepentingan umum. Kebijakan ganti rugi non fisik pada pengadaan tanah berbasis nilai keadilan sosial yang ideal menjadi keniscayaan agar ganti rugi yang diterima oleh pemilik tanah menjadi lebih adil dan manusiawi untuk kesejahteraan hidup setelah tanah mereka dilepaskan untuk kepentingan umum. Kebijakan ganti rugi non fisik yang ideal ini akan berhasil apabila pemerintah dalam hal ini adalah Panitia Pengadaan Tanah (P2T) konsisten memberikan ganti rugi non fisik yang layak dan penentuan besarnya ganti rugi pun berdasarkan kesepakatan dalam musyawarah. Pemerintah (P2T) juga harus terbuka (transparan) memberikan informasi data penilaian dari Penilai Harga Tanah (PHT) kepada warga yang berhak, sehingga dihasilkan keputusan yang adil dan diterima semua pihak yang berkepentingan.

\section{Kerangka Teori}

Untuk mengungkap problematika yang telah diajukan pada perumusan masalah akan diajukan beberapa teori sebagai kerangka berpikir yang menjadi pisau analisis. Teori pokok yang akan digunakan sebagai pisau analisis utama adalah teori bekerjanya hukum dalam masyarakat dari William J. Chambliss dan Robert B. Seidman. Atas dasar teori pokok tersebut ada beberapa teori penunjang untuk menganalisis permasalahan dalam tulisan ini, akan digunakan berbagai teori sebagai pisau analisis yaitu teori Konflik, teori Keadilan John Rawl dan teori hukum progresif.

Terkait dengan keadilan dalam penentuan ganti rugi non fisik dalam proses pengadaan tanah, maka kehadiran hukum dalam masyarakat diantaranya adalah untuk mengintegrasikan dan mengkoordinasikan kepentingan-kepentingan yang berbenturan satu sama lain yang diintegrasikan sedemikian rupa sehingga bisa ditekan 
sekecil-kecilnya. Pengorganisasian kepentingan-kepentingan yang berbenturan itu dilakukan dengan membatasi dan melindungi kepentingan-kepentingan tersebut.

Terkait dengan kebijakan ganti rugi non fisik dalam pengadaan tanah untuk kepentingan umum yang berkeadilan, hal mana apabila hukum dipandang secara sosiologis di dalamnya terkandung himpunan nilai-nilai, kaidah-kaidah dan pola perikelakuan yang berhubungan dengan kebutuhan-kebutuhan pokok manusia. Hal ini sesuai dengan teori hukum progresif, dimana hukum diciptakan untuk manusia dan saling mempengaruhi dengan berbagai komponen di sekitar manusia.

\section{Hasil Penelitian Terdahulu}

Sejauh pengamatan penulis, dengan melakukan penelusuran kepustakaan, internet dan bentuk publikasi lainnya, belum dijumpai suatu uraian mendalam ataupun penelitian yang memiliki fokus studi mengenai kebijakan ganti rugi non fisik pada pengadaan tanah untuk kepentingan umum yang berkeadilan sosial di Indonesia. Ditemukan banyak penelitian mengenai pengadaan tanah yang hanya membahas ganti rugi fisik yang selalu menimbulkan konflik antara pemerintah dan warga yang terkena dampak proyek pembangunan untuk kepentingan umum.

\begin{tabular}{|c|c|c|c|c|}
\hline \multicolumn{5}{|c|}{ lahulu } \\
\hline No & $\begin{array}{l}\text { Peneliti/Penulis/ } \\
\text { Asal Perguruan } \\
\text { Tinggi/Tahun }\end{array}$ & $\begin{array}{c}\text { Judul } \\
\text { Penelitian }\end{array}$ & Fokus Kajian & Unsur Kebaruan \\
\hline 1. & $\begin{array}{l}\text { Dr. Ir. Drs. Jarot } \\
\text { Edy Sulistyono, } \\
\text { Msi /Universitas } \\
\text { Brawijaya, Malang } \\
2006\end{array}$ & \begin{tabular}{|l|} 
Pengadaan \\
TanahUntuk \\
Pembangunan \\
di Daerah \\
Perkotaan \\
\end{tabular} & \begin{tabular}{l|} 
Model Interaktif \\
Implementasi \\
Kebijakan \\
Pengadaan Tanah \\
Untuk Infrastruktur, \\
Pemukiman dan \\
Perdagangan di Kota \\
Malang.
\end{tabular} & $\begin{array}{l}\text { Konsep Kebijakan Ganti } \\
\text { Rugi Non Fisik Pada } \\
\text { Kebijakan Pengadaan } \\
\text { Tanahuntuk Kepentingan } \\
\text { umum Yang Berbasis } \\
\text { Nilai Keadilan. }\end{array}$ \\
\hline 2. & $\begin{array}{l}\text { Dr. Bemhard } \\
\text { Limbong/ } \\
\text { Universitas } \\
\text { Padjajaran } \\
\text {,Bandung/2011 }\end{array}$ & $\begin{array}{l}\text { Perlindungan } \\
\text { Hukum Bagi } \\
\text { Pemegang Hak } \\
\text { atastanah } \\
\text { Dalam } \\
\text { Pengadaan } \\
\text { TanahBagi } \\
\text { Pembangunan } \\
\text { Untuk } \\
\text { Kepentingan } \\
\text { Umum }\end{array}$ & $\begin{array}{l}\text { Perlindungan hukrm } \\
\text { bagipemeganghak } \\
\text { atas tanahdalam } \\
\text { proses pengadaan } \\
\text { tanah denganganti } \\
\text { rugi fisik dari aspek } \\
\text { ekonomi dan sosial. }\end{array}$ & $\begin{array}{l}\text { Perlindungan hukum bagi } \\
\text { warga yangterkena } \\
\text { dampak pembangunan } \\
\text { untuk kepentinganumum } \\
\text { dengan memberikan ganti } \\
\text { rugi non fisik. }\end{array}$ \\
\hline 3. & $\begin{array}{l}\text { Dr.Farida Fitryah, } \\
\text { SH, MH/ } \\
\text { Universitas } \\
\text { Brawijaya, Malang } \\
2012\end{array}$ & \begin{tabular}{|l|} 
Pengadaan \\
TanahDan \\
Sertifikasi Hak \\
atastanah \\
Untuk \\
Transmigrasi
\end{tabular} & $\begin{array}{l}\text { Pengadaan Tanah } \\
\text { untuk Tanah Adat } \\
\text { yang dilakukan tidak } \\
\text { memenuhi kebjiakan } \\
\text { UU yang berlaku }\end{array}$ & $\begin{array}{l}\text { Pengadaan Tanahuntuk } \\
\text { kepentingan umumyang } \\
\text { menerapkan kebijakan } \\
\text { ganti rugi non fisik yang } \\
\text { berkeadilan substansial. }\end{array}$ \\
\hline
\end{tabular}

Dari beberapa judul di atas, maka penelitian dengan mengkonstruksi kebijakan ganti rugi non fisik pada pengadaan tanah untuk kepentingan umum berbasis nilai keadilan sosial belum pernah dilakukan. Penelitian ini sangat penting untuk diteliti dan dikaji dalam sebuah disertasi, didasarkan banyaknya konflik yang berkaitan dengan penentuan bentuk dan besarnya ganti rugi non fisik di masyarakat yang sampai sekarang masih menimbulkan banyak permasalahan. Hal ini disebabkan tidak diterapkannya secara benar ketentuan ganti rugi non fisik pada pengadaan tanah untuk kepentingan umum yang telah diatur dalam Pasal 33 huruf $\mathrm{f}$ UUPT Tahun 2012, sehingga terjadi pelanggaran atas penghormatan kepemilikan hak atas tanah rakyat yang telah diamanatkan Konstitusi UUD NRI Tahun 1945 dan Pancasila.

\section{Permasalahan dan Tujuan Penelitian}

Dari penelitian-penelitian yang terdahulu belum pernah diteliti mengenai penentuan bentuk dan besarnya ganti rugi non fisik sehingga menimbulkan konflik yang berkepanjangan antara pemerintah dan warga masyarakat. Oleh karena itu, permasalahan penelitian ini adalah (1) Mengapa terjadi konflik mengenai ganti rugi non fisik pada pengadaan tanah untuk kepentingan umum di Desa Lemahireng Kabupaten Semarang? (2) Bagaimana konstruksi baru kebijakan ganti rugi non fisik pada pengadaan tanah untuk kepentingan umum?

\section{Metode Penelitian}

Penelitian ini menggunakan metode penelitian kualitatif yang diharapkan dapat ditemukan makna-makna yang tersembunyi dibalik obyek maupun subyek yang akan diteliti. Penelitian dengan pendekatan Socio Legal dengan metode dan teori ilmu sosial tentang hukum untuk membantu peneliti melakukan analisis (Rahardjo, 2009). Pendekatan ini dilakukan untuk memahami hukum dalam konteks masyarakatnya (Zamroni, 1992). Pendekatan ini tetap dalam ranah hukum, hanya perspektifnya berbeda. Dalam penelitian ini melihat fakta penentuan bentuk dan besarnya ganti rugi yang terjadi pada pengadaan tanah di Desa Lemah ireng 
Kabupaten Semarang.

Data dalam penelitian ini diperoleh melalui kegiatan-kegiatan observasi, interview, interpretasi dokumen (teks), serta personal experience. Dalam metode penelitian kualitatif, jenis dan cara observasi dipakai sebagai jenis observasi yang dimulai dari cara kerja deskriptif, kemudian observasi berfokus dan pada akhirnya observasi terseleksi (Faisal, 1990). Sesuai dengan paradigma penelitian ini, dalam melakukan observasi peneliti akan mengambil posisi sebagai participant observer artinya peneliti menyatu dengan apa yang ditelitinya yang berakibat peneliti dekat dengan obyek yang dikajinya. Peneliti adalah instrumen utama dalam pengumpulan data. Indepth interview dilakukan dengan pertanyaan-pertanyaan terbuka (open ended), namun tidak menutup kemungkinan akan dilakukan pertanyaanpertanyaan tertutup (closed ended) terutama untuk informan yang memiliki banyak informasi tetapi ada kendala dalam mengelaborasi informasinya tersebut (Nasution, 1992).

Di samping memanfaatkan dokumentasi dan observasi, pengumpulan data terutama dilakukan melalui wawancara dengan para responden. Kegiatan pengumpulan data meliputi, pertama mencari data primer kemudian data sekunder. Data sekunder adalah data yang telah dikumpulkan dan disistematisir oleh pihak lain dan digunakan juga dalam penelitian ini (Stewart, 1984).

Teknik untuk menemukan data primer, dilakukan melalui wawancara secara bebas/terbuka atau tak terstruktur secara langsung dengan responden yang ditemui, yang dianggap penting untuk memberikan data dalam penelitian ini. Meskipun terdapat data statistik yang didapat melalui data sekunder maupun wawancara terpadu, tetapi penelitian ini lebih bersifat field research dengan menggunakan pendekatan verstehen atau hermeneutic. Di samping itu, observasi dilakukan dalam rangka untuk memperoleh data tentang lokasi penelitian dalam aspek fisiknya, misalnya pola penggunaan, penguasaan tanah, dan perilaku-perilaku warga yang berhak.
Berdasarkan wawancara dan temuan observasi, selanjutnya didiskusikan secara m e n a la m ba i d e ngan para informan/responden maupun dengan para informan kunci.

\section{B. Hasil dan Pembahasan \\ 1. Social Setting Masyarakat Desa Lemah Ireng}

Desa Lemah Ireng merupakan salah satu desa yang berada di Kecamatan Bawen, Kabupaten Semarang yang terletak di dataran tinggi dengan tanahnya yang berbukit. Luas desa ini yaitu $601.750 \mathrm{Ha}$, dengan batas desa di sebelah utara berbatasan dengan Desa Jatijajar, sebelah timur berbatasan dengan Desa Kandangan, sebelah selatan berbatasan dengan Desa Bawen, dan di sebelah barat berbatasan dengan Desa Randugunting. Berdasarkan data monograsi dari Kantor Desa Lemah Ireng, Desa Lemah Ireng yang mempunyai empat dusun ini yaitu dusun Kenongo, Kalisalak, Klowoh, dan Krajan. Dusun Krajan merupakan dusun yang memiliki warga paling banyak, hal ini disebabkan pusat pemerintahan desa berada di dusun Krajan dan akses transportasinya juga sudah bagus.

Penduduk Desa Lemah Ireng mencapai 7.500 jiwa dan mayoritas mempunyai mata pencaharian bertani, hal ini sesuai dengan kondisi desa yang banyak terdapat sawah. Mereka ada juga yang bekerja sebagai peternak, tukang ojek dan menjadi buruh pabrik. Penduduk desa Lemah Ireng sangat meyakini bahwa tanah memiliki nilai ekonomis, merupakan sumber daya alam yang sangat berharga bagi kehidupan mereka, selain itu juga memiliki nilai sosial dan nilai budaya yang tinggi. Secara geografi,s Desa Lemah Ireng adalah perbukitan dan masih banyak membentang sawah,ladang dan untuk sebelah utara di batasi perbukitan perkebunan karet. Sumber mata air utama untuk kehidupan sehari-hari masih mengandalkan curah hujan yang tersimpan dalam sendang (kolam) juga sumur. Oleh karena itu sawah pun masih mengandalkan air hujan. Setiap saat masih terlihat penduduk Desa Lemah Ireng yang berprofesi sebagai petani membajak sawahnya menggunakan sapi. 
Dari segi pendidikan, mayoritas penduduk Desa Lemah Ireng rata-rata hanya sekolah dasar (SD), sekolah tingkat pertama (SLTP) dan sekolah Menengah Tingkat Atas (SMA). Selain sekolah formal ada juga yang sekolah di madrasah atau belajar di sekolah keagamaan dalam hal ini adalah nyantri di pondok pesantren. Putus sekolah masih di temui karena berbagai hal misalnya kurangnya biaya dan tidak ada dukungan dari keluarga.

Masyarakat Desa Lemah Ireng masih melakukan kegiatan adat yang sampai saat ini dan masih di jalankan antara lain adalah Nyadran di makam leluhur (punden Desa Lemah Ireng) setahun sekali dan di ikuti mayoritas seluruh warga desa. Kenduri diadakan setiap ada kegiatan tertentu misalkan malam tahun baru jawa di perempatan atau di musholamushola yang ada di Lemah Ireng dan malam jumat pahing di punden makam Nyai Ireng. Acara tersebut di pimpin oleh tokoh masyarakat yaitu Bpk.Mudin atau mbah sarekat(juru kunci punden) atau wakilnya yaitu para ulama dan tokoh masyarakat yang di anggap mampu untuk memimpin acara adat tersebut. Sedangkan adat turun - temurun masih berlaku baik itu yang keseharian maupun yang tahunan misalnya gotong royong membangun rumah, kerja bakti atau proses ritual adat kampung seperti sunatan,perkawinan ,atau juga untuk urusan melahirkan. Kalau ritual kematian mungkin masih umum di mana-mana seperti tahlilan di 7 hari setelah kematian dan 40 hari setahun, dan nyewu (seribu hari sejak kematian) yang diisi dengan tahlillan. Ritual sedekah desa di adakan habis panen dengan digelarnya wayang kulit sehari semalam.

Dengan demikian, penduduk Desa Lemah Ireng menganggap bahwa tanah merupakan sumber kehidupan yang sangat penting bagi kehidupan mereka, karena hidup mereka sehari-hari sangat bergantung pada tanah baik dari segi ekonomi, sosial maupun budaya.

\section{Konflik mengenai ganti rugi non fisik pada pengadaan tanah untuk kepentingan umum \\ Hampir setiap warga yang berhak di} Desa Lemah Ireng merasa dirinya tertekan dengan jumlah uang ganti rugi yang tidak layak, dibuktikan dengan sulitnya mencari lahan baru sebagai pengganti tempat tinggal bagi mereka yang tinggal di kota-kota besar karena tingginya harga bahan bangunan dan masih ditambah lagi dengan kehilangan usaha/pekerjaan yang menopang kehidupan keluarganya. Masyarakat desa yang terkena pengadaan tanah mencari tempat pengaduan (keberatan) ke wakil rakyat (DPRD Provinsi Jawa Tengah), Komnas HAM, Ombusman juga KP2KKN karena mereka merasa tertekan karena intimidasi aparat pemerintah sendiri, tetapi akhirnya berubah sikap menjadi anarkis karena tidak ada hasil dari pengaduan mereka tersebut.

Beberapa warga desa Lemah Ireng menghadapi kehidupan yang lebih buruk dari sebelum tanahnya dibebaskan dan ini mengakibatkan gejolak sosial, demi mempertahankan keberadaan kehidupannya, k e luarganya d a n k h id u pa n bermasyarakatnya baik bidang adat budaya dan bidang keagamaan. Penilaian ganti rugi fisik yang tidak transparan (tidak terbuka) mengakibatkan warga tidak percaya perhitungan yang dinilai Penilai Harga Tanah (PHT). Padahal berdasarkan Penjelasan Pasal 2 huruf (e) UUPT tahun 2012 bahwa Pengadaan Tanah untuk pembangunan dilaksanakan dengan memberikan akses kepada masyarakat untuk mendapatkan informasi yang berkaitan dengan Pengadaan Tanah (asas keterbukaan dalam pengadaan tanah untuk kepentingan umum).

Ketidaksepakatan mengenai besarnya ganti rugi, selain tidak adanya keterbukaan data penilaian dari PHT, juga disebabkan tim penaksir harga tidak menilai ganti rugi non fisik yang diderita warga yang terkena dampak proyek jalan tol Semarang - Solo. Tim penaksir harga hanya bekerja berdasarkan surat tugas yang diberikan P2T, sebatas menilai untuk ganti rugi fisik semata.

Dalam temuan tidak dinilai (dihitung) ganti rugi non fisik dalam pengadaan tanah di Desa Lemah Ireng. Padahal berdasarkan 
Pasal 33 huruf (f) UUPT Tahun 2012 telah disebutkan dengan jelas bahwa ganti rugi yang dapat di nilai (ganti rugi non fisik) dinilai. Kriterianya dijelaskan dalam Penjelasan Pasal 33 huruf (f) tersebut. Penjelasan Pasal 33 Huruf f UU No. 2 Tahun 2012, yang dimaksud dengan "kerugian lain yang dapat dinilai" adalah kerugian nonfisik yang dapat disetarakan dengan nilai uang, misalnya kerugian karena kehilangan usaha atau pekerjaan, biaya pemindahan tempat, biaya alih profesi, dan nilai atas properti sisa.

Pemerintah seharusnya mencarikan jalan keluar bagi kehidupan warga yang berhak yang akan menderita apabila kehilangan tanahnya sebagai sumber kehidupannya. Hal ini terkait dengan tugas umum dari pemerintah sendiri mempunyai kewajiban untuk melindungi, mengamankan dan mensejahterakan masyarakat secara keseluruhan termasuk semua warga masyarakat yang terkena dampak dari pembangunan pengadaan tanah. Tidak diterapkannya ketentuan ganti rugi non fisik dalam proses pengadaan tanah untuk kepentingan umum menunjukkan hukum yang tidur (sleeping law) berakibat tidak tercapainya kesejahteraan rakyat sebagaimana diamanatkan oleh konstitusi. Hal ini disebabkan para pelaksana hukum tidak konsisten menjalankan apa yang telah diperintahkan dalam kebijakan pengadaan tanah yang berlaku.

Warga Desa Lemah Ireng tetap menuntut pemerintah transparan dengan memperlihatkan hasil penilaian dari tim penilai harga tanah (tim appraisal independen) terkait penilaian obyek pengadaan tanah. Eksekusi yang dilakukan pemerintah terhadap obyek pengadaan tanah merupakan bentuk pelanggaran hukum karena proses hukum masih berjalan dan putusan kasasi belum turun. Berbagai konflik tersebut, bermula dari digunakannya kekuasaan dan wewenang lembaga yang ada di desa/ kelurahan untuk menempatkan pihak pemilik tanah pada posisi bawah. Benar apa yang digambarkan oleh Ralf Dahrendorf, bahwa masyarakat merupakan persekutuan yang terkoordinasi secara paksa (imperatively coordinated associations) (Dahrendorf, 1986).
Konflik yang banyak terjadi terkait ganti rugi non fisik dalam proses pengadaan tanah untuk kepentingan umum yang dilakukan pemerintah, harus dipandang sebagai penolakan masyarakat terhadap tindakan pemerintah dalam mengatur, mengurus dan mengawasi tanah. Konflik tersebut merefleksikan bahwa pengaturan, pengurusan dan pengawasan atas tanah yang dilakukan negara selama ini, belum dapat memberikan kesejahteraan yang berkeadilan kepada masyarakat. Karena itu, untuk dapat mewujudkan kesejahteraan rakyat yang berkeadilan, fenomena konflik, hendakna direspon untuk melakukan perbaikanperbaikan, agar hukum benar-benar dapat mewujudkan tujuannya untuk membahagian manusia dan masyarakat.

Terkait persoalan konflik antara pemerintah (P2T) dengan masyarakat Desa Lemah Ireng ini dianalisis dengan teori konflik Ralf Dahrendorf menjelaskan bahwa konflik terjadi karena adanya perbedaan kekuasaan dan kepentingan dalam sistem sosial. Oleh karena itu, terhadap konflikkonflik yang berpotensi muncul dalam masyarakat yakni antara negara dan warga ini, maka kebijakan negara harus mensikapi dan mengelola konflik itu sebagai bagian dari realitas sosial masyarakat yang tak terselesaikan. Negara seharusnya menghormati hak-hak mereka, baik hak atas identitas, hukum, dan sumber-sumber hidup mereka yang di lindungi oleh konstitusi.

Demi terwujudnya tujuan negara hukum agar tercapai kesejahteraan rakyat yang berkeadilan sosial bagi seluruh rakyat, maka perlu diberikan ganti rugi non fisik dalam pengadaan tanah bagi untuk kepentingan umum bagi warga yang terkena dampak pengadaan tanah tersebut, didasarkan pada nilai-nilai luhur Proklamasi dan Pancasila dengan konseptualisasi nilai-nilai keadilan secara progresif berkesejahteraan.

\section{Konstruksi Baru Kebijakan Ganti Rugi Non Fisik Pada Pengadaan Tanah Untuk Kepentingan Umum}

Dalam realitasnya, penentuan bentuk dan besarnya ganti rugi menekankan pada pencarian kebenaran formil, seringkali 
menimbulkan ketidakpuasan para pihak atas putusan P2T. Hal ini terjadi disebabkan P2T menafsirkan Pasal 33 huruf (f) UUPT Tahun 2012 secara teks formil yang tidak mempertimbangkan nilai-nilai di masyarakat. Oleh karena itu, berarti penentuan bentuk dan besarnya ganti rugi yang berpijak pada kebenaran formil belum dapat sepenuhnya memberikan perlindungan dan jaminan terciptanya keadilan bagi para warga yang mengalami kerugian akibat pembangunan untuk kepentingan umum.

Dalam konteks keadilan yang terkandung dalam hukum yang berwujud peraturan, terlihat dalam pengaturan ganti rugi non fisik sebagaimana diatur dalam Pasal 33 huruf (f) yang menyatakan: "Penilaian besarnya nilai ganti rugi oleh penilai dilakukan bidang per bidang tanah, meliputi: (f) kerugian lain yang dapat dinilai." Di sini P2T menafsirkan kerugian yang dapat dinilai sebagai ganti rugi fisik yang dapat di nilai, padahal dalam Penjelasan Pasal 33 huruf (f) UUPT Tahun 2012 menyatakan bahwa : "Yang dimaksud dengan kerugian lain yang dapat dinilai adalah kerugian nonfisik yang dapat disetarakan dengan nilai uang, misalnya kerugian karena kehilangan usaha atau pekerjaan, biaya pemindahan tempat, biaya alih profesi, dan nilai atas properti sisa.“ Hukum yang terwujud dalam peraturan UUPT Tahun 2012 memang mengandung nilai-nilai keadilan bagi warga yang berhak atas kehilangan usaha atau pekerjaan, biaya pindah tempat, alih profesi dan nilai atas profesi sisa. Akan tetapi dalam praktek halhal tersebut tidak ikut dinilai dalam proses pengadaan tanah, sehingga putusan P2T tentang penentuan bentuk dan besarnya ganti rugi selama ini tidak memberikan ganti rugi non fisik pada warga yang berhak.

Hukum progresif berdasar dari asumsi bahwa kehadiran hukum bukan untuk dirinya sendiri, melainkan untuk sesuatu yang lebih luas dan besar, itulah sebabnya ketika terjadi permasalahan di dalam hukum, maka hukumlah yang harus ditinjau dan diperbaiki, bukan manusianya yang dipaksa untuk dimasukkan ke dalam skema hukum. Dalam konteks penentuan bentuk dan besarnya ganti rugi non fisik yang berbasis hukum progresif, perlu diwujudkan keadilan progresif. Oleh karena itu, diperlukan perubahan agar dalam praktek dalam menentukan ganti rugi non fisik dalam proses pengadaan tanah untuk kepentingan umum lebih menekankan pada substansi, sehingga yang dihasilkan adalah keadilan progresif.

Metode menuju terwujudnya keadilan substantif dalam penentuan bentuk dan besarnya ganti rugi non fisik dalam pengadaan tanah untuk kepentingan umum tersebut bisa dilakukan dengan rule breaking yang merupakan karakteristik dalam hukum progresif, dalam bentuk kreativitas P2T apabila mengalami kebuntuan dalam menemukan keadilan substansial yang tidak ditemukan dalam teks peraturan perundangundangan. Dengan demikian dituntut P2T yang berpandangan progresif yang bisa melihat hukum tidak sebatas peraturan semata.Dengan demikian, metode yang bisa dipakai untuk mewujudkan keadilan substansial, yakni metode rule breaking yang merupakan karakteristik dalam hukum progresif.

Pada akhirnya konstruksi baru kebijakan dalam penentuan bentuk dan besarnya ganti rugi non fisik pada pengadaan tanah untuk kepentingan umum berbasis hukum progresif, tidak lain adalah untuk mewujudkan keadilan substansial. Seluruh proses bekerjanya instrumen pelaksana hukum (P2T) tersebut harus bisa diverifikasi ke dalam faktor-faktor keadilan, kesejahteraan, kepedulian kepada rakyat dan lain-lain, yang kesemuanya itu telah terkandung dalam nilai-nilai Pancasila. 


\section{Simpulan}

Beranjak dari data dan pembahasan tersebut di atas, maka dapat ditarik simpulan sebagai berikut:

1. Konflik mengenai ganti rugi non fisik pada pengadaan tanah untuk kepentingan umum

Dalam konteks konflik mengenai penentuan bentuk dan besarnya ganti rugi antara pemerintah dan warga adalah permasalahan keterbukaan dalam informasi data penilaian obyek ganti rugi yang dilakukan oleh tim penilai harga. Makna keterbukaan yang diatur dalam kebijakan pengadaan tanah UUPT Tahun 2012 adalah bahwa pengadaan tanah untuk pembangunan dilaksanakan dengan memberikan akses kepada masyarakat untuk mendapatkan informasi yang berkaitan dengan Pengadaan Tanah. Dalam temuan, pemerintah tidak mengindahkan asas keterbukaan tersebut. Warga sampai menuntut baik secara langsung dengan melakukan demonstrasi di lokasi proyek pembangunan, kantor pemerintah daerah maupun kantor pemerintah provinsi maupun dengan upaya hukum dengan mengajukan ke pengadilan negeri terkait keterbukaan informasi hasil penilaian tersebut. Mereka menginginkan keterbukaan mengenai data-data penilaian yang dibuat oleh Tim Penilai Harga (TPH), akan tetapi mereka tidak pernah mendapatkannya dari pemerintah (P2T).

\section{Konstruksi Baru Kebijakan Ganti Rugi Non Fisik Pada Pengadaan Tanah Untuk Kepentingan Umum}

Beberapa upaya yang harus dilakukan berkenaan dengan rekonstruksi ketentuan ganti rugi no fisik pada kebijakan pemerintah tersebut, adalah :

a. Produk peraturan perundang-undangan terkait ganti rugi non fisik dalam pengadaan tanah yang tidak sesuai dengan landasan nilai Pancasila sebagai rechtsidee harus dilakukan judicial review dan harus segera diganti.

b. Proses pengadaan tanah khususnya dalam penentuan bentuk dan besarnya ganti rugi didukung oleh pemerintahan yang berdasarkan prinsip good governance;

c. Perubahan paradigma dari positivisme menjadi paradigma progresif.

d. Membangun komitmen bersama untuk mewujudkan kesejahteraan masyarakat dari seluruh komponen yang terlibat dalam permasalahan terkait ganti rugi non fisik dalam proses pengadaan tanah untuk kepentingan umum, termasuk komitmen pemangku kepentingan (stakeholder) Pemerintah, dalam bentuk peraturan daerah yang mengatur mengenai ganti rugi non fisik bagi mereka yang terkena dampak akibat pengadaan tanah untuk kepentingan umum.

Di akhir tulisan ini, penulis memberikan saran bahwa untuk penentuan bentuk dan besarnya ganti rugi non fisik pada pengadaan tanah untuk kepentingan umum diperlukan konstruksi baru kebijakan ganti rugi non fisik. Konstruksi dapat dimulai dari perbaikan substansi perundang-undangan yang mengatur mengenai kebijakan ganti rugi non fisik pada pengadaan tanah untuk kepentingan umum. Secara substansi, ketentuan mengenai kriteria dan ukuran/parameter dalam penentuan ganti rugi non fisik dalam pengadaan tanah untuk kepentingan umum hendaknya dicantumkan secara jelas dalam kebijakan pengadaan tanah yang berlaku dengan berbasis nilai keadilan sosial. Konstruksi selanjutnya adalah secara struktural berupa penguatan lembagalembaga yang terkait langsung dengan penentuan ganti rugi non fisik pengadaan tanah untuk kepentingan umum. Bagian lain yang perlu dikonstruksi adalah secara kultural, dimana pemerintah semestinya memperhatikan nilai-nilai yang hidup dalam masyarakat sehingga akan mencegah konflik dalam proses penentuan bentuk dan besarnya ganti rugi non fisik pada pengadaan tanah untuk kepentingan umum.

\section{DAFTAR PUSTAKA}

Dahrendorf, R. (1986). Konflik dan Konflik Dalam Masyarakat Industri, Sebuah Analisa Kritik. Jakarta: CV. Rajawali.

Faisal, S. (1990). Penelitian Kualitatif Dasardasar \& Aplikasinya. Malang: Yayasan Asah Asih Asuh. 
Nasution. (1992). Metode Penelitian Naturalistik Kualitatif. Bandung:

Tarsito.Rahardjo, S. (2009). LapisanLapisan Dalam Studi Hukum. Malang: Bayumedia Publishing.

Stewart, D. W. (1984). Secondary Research, Information, Sources and Methods. London: Sage Publications, Newbury.

Zamroni. (1992). Pengembangan Pengantar Teori Sosial. Yogyakarta: Tiara Yoga. 